Изв. АН Эстонии. Геол., 1990, 39, № 3, 115-122

УДК $553.985+553.982(474.2)$

Велло КАТТАЙ, Эльмар КАЛА, Калле СУУРОЯ

\title{
О РАСПРОСТРАНЕНИИ ПРИРОДНЫХ БИТУМОВ НА ТЕРРИТОРИИ ЭСТОНИИ
}

Вопросы распространения в нижнепалеозойских отложениях Әстонии органического вещества (OB) типа керогена кукерсита и диктионемового сланца, образованного сингенетично по отношению к минеральной составляющей осадочных пород, сравнительно хорошо изучены, чего нельзя сказать об ОВ эпигенетической природы, представленном в виде локальных скоплений природных битумов (ПБ).

Первые упоминания о ПБ в Эстонии относятся к середине XIX века (Озерский, 1844; Eichwald, 1852; Гельмерсен, 1857; Гревингк, 1868 и др.). В этих и появившихся в последующие годы публикациях (Doss, 1900, 1914; Scupin, 1924; Kogerman, 1933; Аарна, 1959; Мüürisepp, 1962; Люткевич, Курбатская, 1964; Palmre, 1967 и др.) приводятся сведения об отдельных находках твердых, жидких и вязких битумов (ТПБ, ЖПБ и ВПБ соответственно) в отложениях палеозоя в их естественных и искусственных обнажениях, а также в керне буровых скважин. В 1968 1971 гг. при геологическом картировании о-ва Хийумаа Э. Кала были зафиксированы ПБ и в неглубокозалегающих (15-50 м) раздробленных породах кристаллического фундамента, которые оказались частью кольцевого вала кратера Кярдла (Кала и др., 1978, 1984).

В ряде работ (Орлов, Успенский, 1936; Люткевич, 1965, 1970; Паасикиви, Закашанский, 1965 и рукописные работы ВНИГРИ, 1938, 1945, 1951,1963 ; а также Управления геологии ЭССР, 1970), выполненных в основном в целях оценки перспектив Прибалтики на нефтеносность, обобщались имеющиеся данные о находках ПБ, список которых по территории Әстонии включал до 25 пунктов. В последние 20 лет в результате проведения геологических съемок, геологоразведочных и горноэксплуатационных работ в западной и северо-восточной частях респуб́лики и на о-ве Хийумаа зафиксировано большое количество новых битумопроявлений, а общее число таких пунктов (п.) - скважин, обнажений, шахт, карьеров, известных к настоящему времени на территории Эстонии, превышает уже 110 , из них почти половина расположена в пределах Кярдлаской структуры (рис. 1, п. 43) (Палукюла) (Каттай и др., 1990).

В настоящей статье обобщаются данные о закономерностях распространения ПБ по стратиграфическим подразделениям, территориальному расположению, фазовому состоянию, особенностям морфологии скоплений битума и условиям их залегания.

Наиболее древними образованиями, в которых зафиксированы ПБ, как уже отмечалось выше, являются нижнепротерозойские кристаллические породы кольцеобразного вала Кярдлаской структуры, которые подняты на поверхность и сильно раздроблены взрывом, происшедшим в идавереское время (средний ордовик). Локальные скопления битумов в породах отмечены в виде налетов полужидкой нефти и асфальта по трещинам и кавернам (Кала и др., 1978, 1984).

Следующий стратиграфический уровень, где обнаружены линзы ТПБ (п. 3,19$)$, - лонтоваский горизонт $\left(E_{1} l n\right)$ нижнего кембрия (Коgerman, 1933). 
В районе северо-эстонского глинта или вблйзи него в разные годы были зафиксированы находки линз ТПБ в глауконитовых песчаниках латорпского горизонта $\left(O_{1} l t\right)$ (п. 2, 3, 21) (Гельмерсен, 1857; Doss, 1914; Müürisepp, 1962). П. Когерман (Kogerman, 1933) указал на присутствие тонких вертикальных жилок асфальтита (п. 18) в известняках волховского горизонта $\left(O_{1} v l\right)$. Имеются сведения о находках мелких включений ТПБ в карбонатных породах кундаского $\left(O_{1} k n\right)$, азериского и ласнамягиского $\left(\mathrm{O}_{2} a s+l s\right)$ горизонтов (п. 1,4$)$ (Гревингк, 1868; Pahlen, 1911). В западной части о-ва Хийумаа в нескольких скважинах (п. 54, 58) отмечены также пятна пропитки битумом пород кундаского и ласнамягиского горизонтов (рис. 2).

Большое число находок ТПБ зафиксировано в промышленной пачке кукерситов кукрузеского горизонта $\left(\mathrm{O}_{2} k k\right)$ на разрабатываемом Эстонском месторождении (п. 5-14). Такие находки имели место в карьере Кютте-Йуд и почти во всех шахтах (Kogerman, 1933; Аарна, 1959; Люткевич, Курбатская, 1964; Каттай, Кундель, 1987 и др.). Можно полагать, что частая встречаемость линз ТПБ в залежи кукерситов не отражает истинной картины их широкой распространенности, а объясняется, вероятно, значительной (на сотни кв. км) плошадью вскрытия отложений данного уровня в горных выработках. В западной части о-ва Хийумаа в ряде скважин (п. 49-52 и др.) известняки кукрузеского горизонта (кукерситов и керогенсодержащих пород в разрезе горизонта здесь нет) имеют пятнистую пропитку вязким битумом, им заполнены отдельные мелкие поры и каверны, отмечены его примазки по трещинам и выщелоченным фаунистическим остаткам. Аналогичные ВПБ отмечены в карбонатных отложениях идавереского $\left(\mathrm{O}_{2} i d\right)$, йыхвиского $\left(\mathrm{O}_{2} j h\right)$, кейлаского $\left(\mathrm{O}_{2} k l\right)$, раквереского $\left(\mathrm{O}_{2} r k\right)$, набалаского $\left(\mathrm{O}_{2-3} n b\right)$, вормсиского $\left(\mathrm{O}_{3}\right.$ vr) горизонтов среднего и верхнего отделов ордовика в керне порядка 70 скважин, пробуренных на острове, причем большинство из них расположено на кольцевом вале Кярдлаской структуры (Каттай и др., 1990). В отдельных случаях наблюдаются и мелкие гнезда, жилки, корочки ТПБ. Кстати, еще в прошлом веке ТПБ в виде гнезд и жилок были отмечены в вормсиских известняках каменоломни Палукюла (Озерский, 1844; Kupffer, 1869). Спустя столетие Х. Пальмре (Palmre, 1967) указал на наличие там же мягкого асфальта и капель нефти. В керне буровых скважин на Кярдлаской структуре наиболее часто зафиксированы ПБ в чистых афанитовых известняках раквереского (пийлсеская свита) и набалаского (паэкнаская свита) горизонтов (табл. 1).

\section{ТАБЛИЦА I}

1-2. Вязкий битум (мальта) по остаткам водорослей в известняке раквереского горизонта (пийлсеская свита). Умен. $\times$ 0,75. Скв. Кярдла № $377 \phi$ (п. 43), глубина 48,5 м.

3. Твердый битум (асфальт) по секущей трещине в глинистых известняках кейлаского горизонта. Увел. X 1,5. Скв. Кярдла № 377ф (п. 43), глубина 76,4 м.

4. Вязкий битум (мальта) в мелких прожилках с кальцитом в афанитовом известняке раквереского горизонта. Умен. $\times 0,75$. Скв. № 351 (п. 53), глубина 53,4 м.

5. Пятна пропитки и мелкие поры, заполненные вязким битумом (мальта) в чистом известняке набалаского горизонта (паэкнаская свита). Умен. × 0,75. Скв. Тубала № $380 \phi$ (п. 43), глубина 58,1 м.

6. Песчаник идавереского горизонта (кярдлаская свита), пропитанный битумом (асфальт). Умен. Х 0,75. Скв. Каусте № 351ф (п. 54), глубина 66,4 м.

\section{ТАБЛИЦА ІІ}

1-2. Линзы твердого битума (асфальтит) в слое кукерсита промышленной пачки Әстонского месторождения. Кар. Кютте-Йуд (п. 5). Умен. × 2,2.

3. Фрагмент контакта твердого битума (асфальтит) и кукерсита. Шахта Эстония (п. 11). Увел. $\times 1,5$.

4. Доломит поркуниского горизонта с порами, заполненными твердым битумом (темносерый цвет), и мелкая линза битума (черный цвет). Умен. $\times$ 0,75. Скв. Д-43 (п. 65), глубина $45,6 \mathrm{~m}$, 
ТАБЛИЦА I
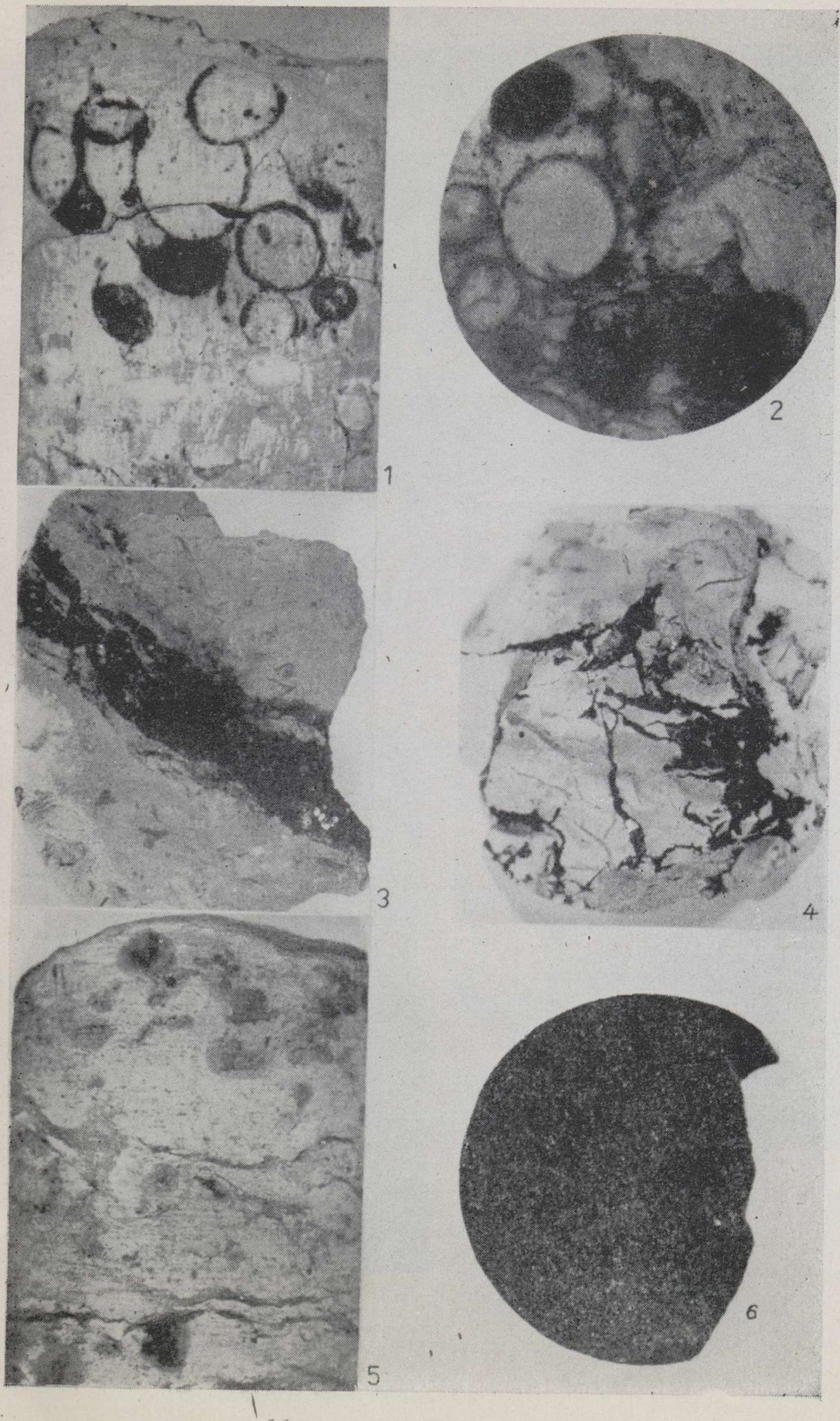
蒠
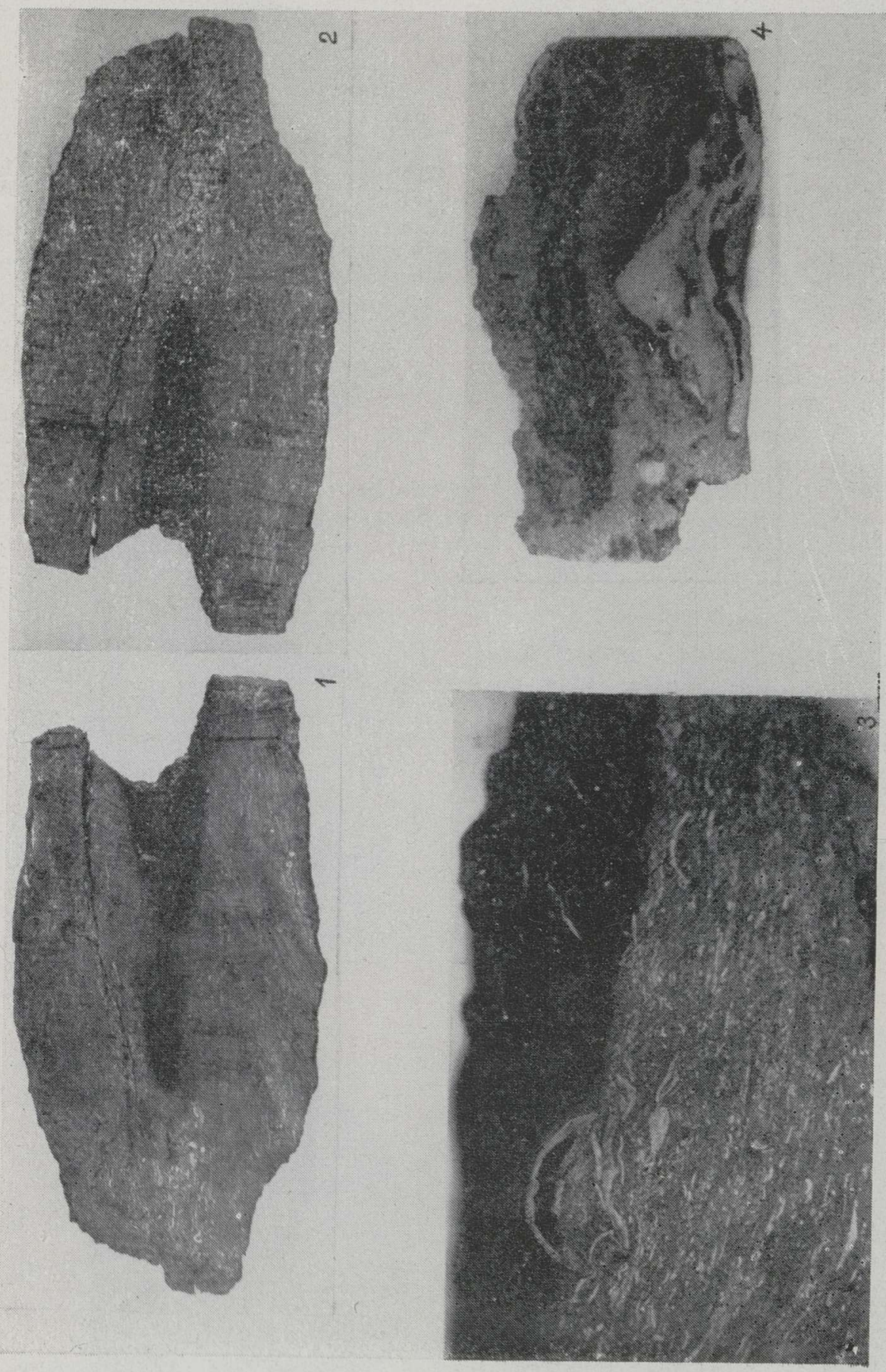


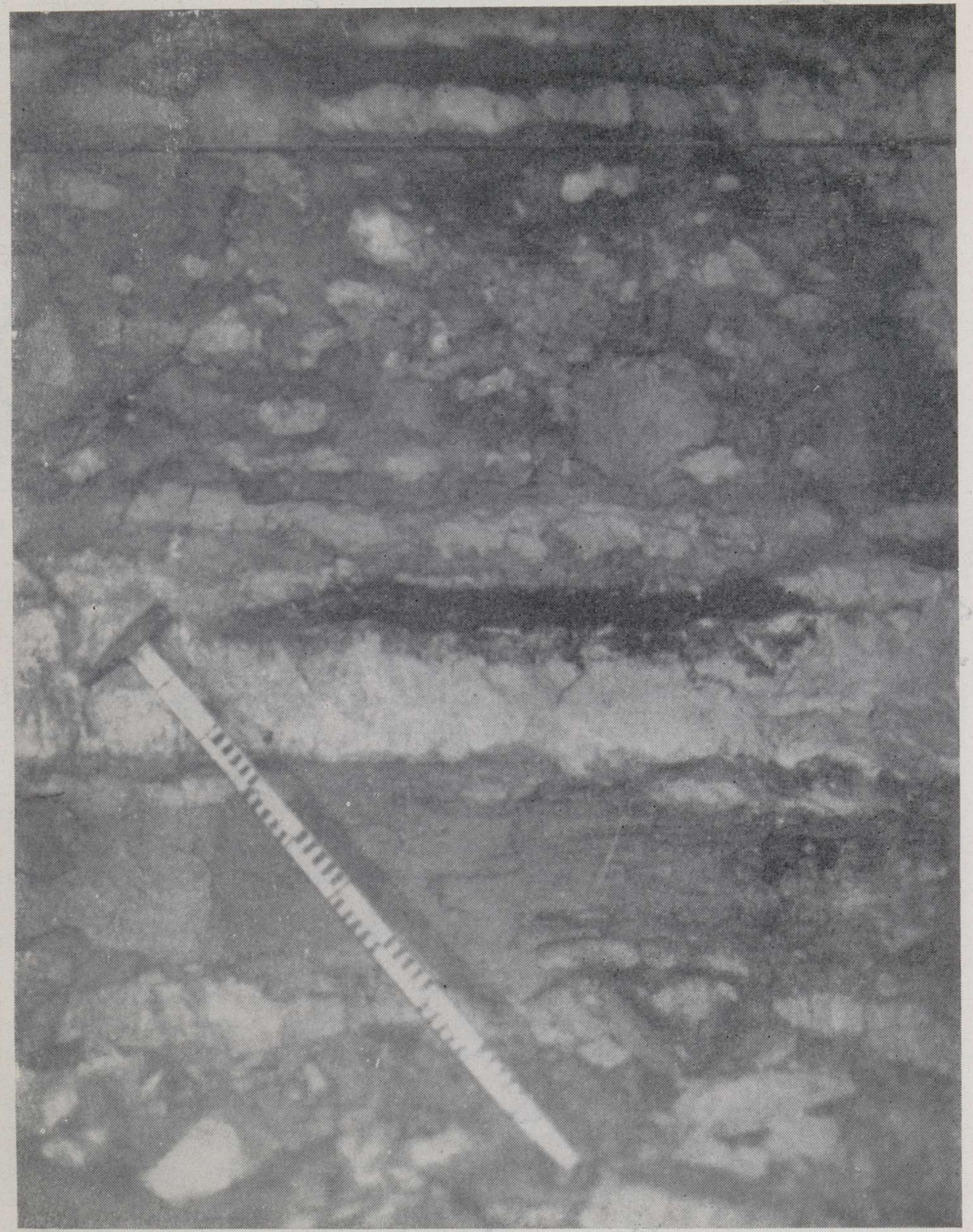

Фото. ПЛлоская линза твердого битума (асфальтит) в прослое известняка «плита» промышленной пачки кукерсита Ленинградского месторожденйя (шахта № 3). Светлый тон - известняк, серый - кукерсит, черный - асфальтит. 


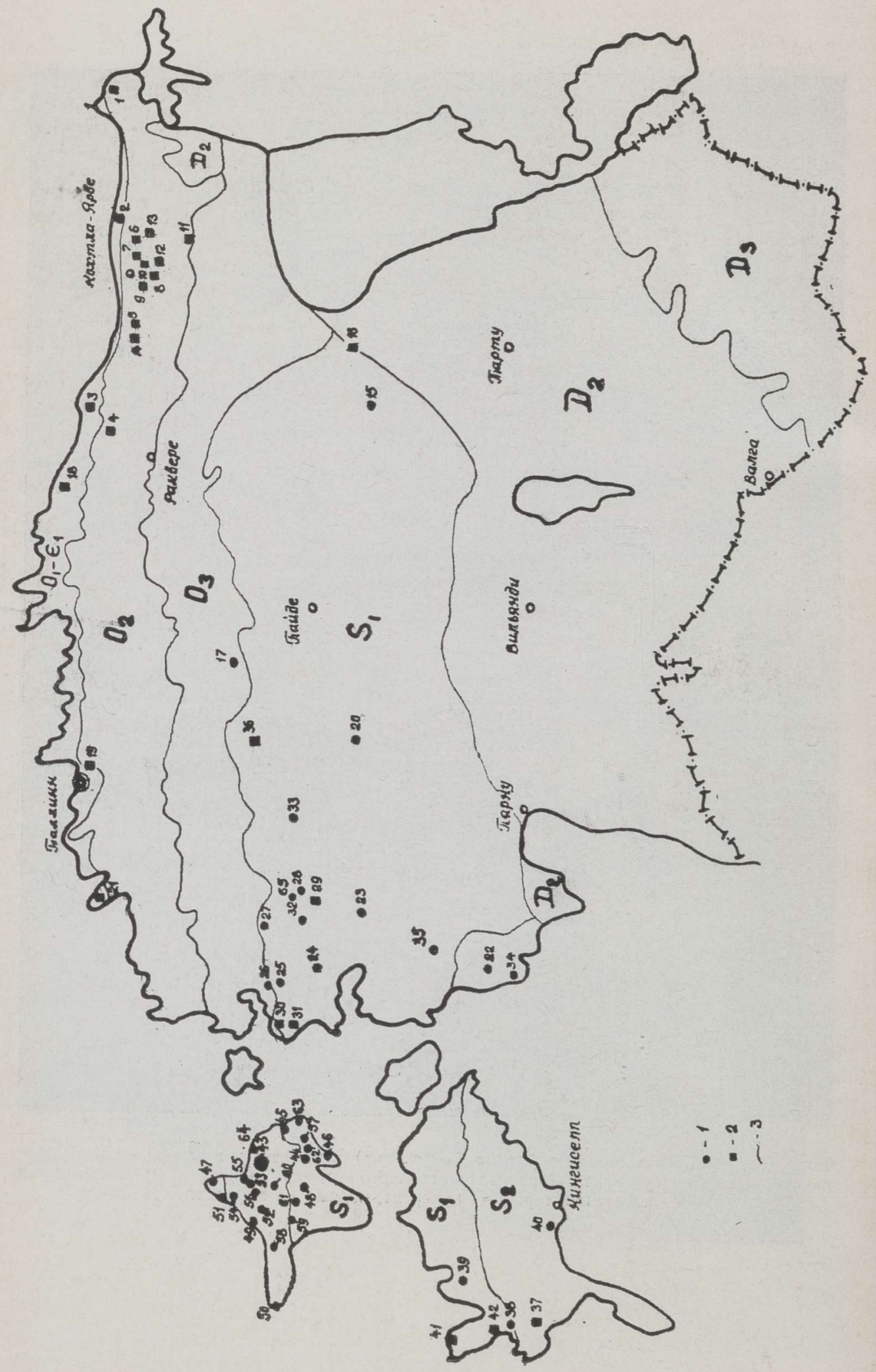


Рис. 1. Схема расположения пунктов битумопроявлений. 1 - жидкие и вязкие битумы, 2 - твердые битумы, 3 - границы стратиграфических подразделений. Перечень пунктов: 1 - обнажение (обн.) Нарва $\left(O_{1} k n\right) ; 2-$ обн. Тойла $\left(O_{1} l t\right) ; 3$ - карьер (кар.) Кунда $\left(O_{1} l t, E_{1} l n\right) ; 4$ - кар. Ару $\left(O_{2} l s\right) ; 5$ - кар. Кютте-Йуд $\left(O_{2} k k\right) ; 6$ - шахта (ш.) Кукрузе $\left(\mathrm{O}_{2} k k\right) ; 7$ - ш. Кява $\left(\mathrm{O}_{2} k k\right) ; 8$-ш. Сомпа $\left(\mathrm{O}_{2} k k\right) ; 9$ - ш. Кохтла $\left(\mathrm{O}_{2} k k\right)$; 10 - ш. № $4\left(\mathrm{O}_{2} k k\right) ; 11$ - ш. Әстония $\left(\mathrm{O}_{2} k k\right) ; 12$ - ш. Виру $\left(\mathrm{O}_{2} k k\right) ; 13$ - ш. Таммику $\left(\mathrm{O}_{2} k k\right) ; 14$ - ш. Кивиыли $\left(\mathrm{O}_{2} k k\right) ; 15$ - скважина (скв.) Паламузе № $4\left(S_{1} r k\right)$; 16 - скв. Саape № $72\left(S_{1} j r\right) ; 17$ - скв. Арду $\left(O_{3} p r g\right) ; 18$ - обн. Ванамыйза $\left(O_{1} v l\right)$; 19 - скв. Таллинн $\left(\mathrm{E}_{1} \ln \right) ; 20$ - скв. Кынну № $300\left(O_{3}\right.$ prg $) ; 21$ - обн. Палдиски $\left(O_{1} l t\right) ; 22$ - скв. Варбла № $502\left(S_{2} p d\right) ; 23$ - скв. Паэкюла № $301\left(S_{1} r k\right) ; 24$ - скв. Мартна $\left(S_{1} r k, O_{3}\right.$ prg, $\left.O_{2} r k\right) ; 25$ - скв. Таэбла № $120\left(O_{3} p r\right) ; 26$ - скв. Таэбла № 117 $\left(\mathrm{O}_{3} \mathrm{pr}\right) ; 27$ - скв. Паливере № $354\left(\mathrm{O}_{3} \mathrm{prg}\right) ; 28$ - скв. Кулламаа № Д-223 $\left(\mathrm{O}_{3} \mathrm{pr}\right)$; 29 - обн. Кулламаа $\left(S_{1} r k\right) ; 30-$ обн. Рохукюла $\left(S_{1} r k\right) ; 31^{1}-$ кар. Пуску $\left(\mathrm{S}_{1} j r\right)$; 32 - скв. Соояэре № $330\left(S_{1} r k\right) ; 33$ - кар. Оргита $\left(S_{1} r k\right) ; 34$ - обн. Матсикюла $\left(S_{1} r k\right)$; 35 - обн. Ванакюла $\left(S_{1} r k\right) ; 36$ - обн. Ида-Уркад $\left(O_{3} p r\right) ; 37$ - кар. Люманда $\left(S_{2} p d\right)$; 38 - скв. Вики $\left(O_{3}\right.$ prg $) ; 39$ - скв. Мустъяла $\left(S_{1} j g, S_{1} r k\right) ; 40$ - скв. Кингисепп № 2 $\left(S_{1} r k, O_{3}\right.$ prg, $\left.O_{2-3} n b\right) ; 41-$ обн. глинта Сааремаа $\left(S_{1} j n\right) ; 42$ - обн. Яагараху $\left(S_{1} j g\right)$; 43 - кар. Палукюла $\left(O_{3} v r, O_{2-3} n b\right)$ и группа из 51 скважины $\left(O_{3}\right.$ prg $-O_{2} j h$, PR); 44 - скв. Ваэмла $\left(S_{1} r k\right) ; 45$ - обн. Пюхалепа $\left(S_{1} j r\right) ; 46-$ обн. Кассари $\left(S_{1} j r\right) ; 47-$ обн. глинта Хийумаа $\left(O_{1} k n\right) ; 48$ - обн. Путкасте $\left(S_{1} j r\right) ; 49$ - скв. Кыргесааре $\left(O_{2}\right.$ on, $\left.\mathrm{O}_{2} \mathrm{id}, \mathrm{O}_{2} k k\right) ; 50$ - скв. Қалана № $393\left(\mathrm{O}_{2} \mathrm{id}, \mathrm{O}_{2} k k\right) ; 51$ - скв. Тахкуна № $396\left(\mathrm{O}_{2} k k\right)$; 52 - скв. Курисо № $399\left(\mathrm{O}_{2} \mathrm{id}, \mathrm{O}_{2} k k\right) ; 53$ - скв. № $351\left(\mathrm{O}_{2} r k\right) ; 54-$ скв. Каусте № $351 \phi\left(\mathrm{O}_{2} \mathrm{kl}-\mathrm{O}_{2} \mathrm{kk}, \mathrm{O}_{2} \mathrm{ls}\right) ; 55-$ скв. Таресте № $352 \phi\left(\mathrm{O}_{2} \mathrm{rk}, \mathrm{O}_{2} \mathrm{kl}-\mathrm{O}_{2} \mathrm{id}\right) ; 56-$ скв. Кидасте № 353ф $\left(\mathrm{O}_{2} \mathrm{kl}, \mathrm{O}_{2} \mathrm{id}\right) ; 57-$ скв. Ыунаку № $354 \phi\left(\mathrm{O}_{3} \mathrm{prg}\right) ; 58-$ скв. Луйдья № 357ф $\left(\mathrm{O}_{2} \mathrm{id}, \mathrm{O}_{2} \mathrm{kk}, \mathrm{O}_{2} \mathrm{ls}, \mathrm{O}_{1} \mathrm{kn}\right) ; 59$ - скв. Лейгри № 358ф $\left(\mathrm{O}_{3} \mathrm{prg}, \mathrm{O}_{2} \mathrm{jh}-\mathrm{O}_{2} \mathrm{kk}\right)$; 60 - скв. Мяэвли № 359ф $\left(\mathrm{O}_{2-3} n b, \mathrm{O}_{2} \mathrm{kl}\right) ; 61$ - скв. Пихла № 361ф $\left(\mathrm{O}_{2}\right.$ id $) ; 62$ - скв. Ниидикюла № 365ф ( $\left.\mathrm{O}_{3} \mathrm{prg}\right) ; 63$ - скв. Соонлепа № 366ф $\left(\mathrm{O}_{3} \mathrm{pr}, \mathrm{O}_{3} \mathrm{prg}\right) ; 64$ - скв. Хийесаape $\mathrm{K}-15\left(\mathrm{O}_{2} k k, \mathrm{O}_{2} \mathrm{rk}\right) ; 65$ - скв. Д-43 $\left(\mathrm{O}_{3} \mathrm{pr}\right)$

В скобках указаны горизонты, в которых вскрыты природные битумы.

Битумопроявления в отложениях пиргуского $\left(\mathrm{O}_{3} \mathrm{prg}\right)$, поркуниского $\left(\mathrm{O}_{3} \mathrm{pr}\right)$ горизонтов верхнего ордовика установлены в ряде скважин в Западной (п. 24-27), Центральной (п. 17, 20) Эстонии, на о-ве Хийумаа (п. 57,63 ) и о-ве Сааремаа (п. 38,40$)$. ВПБ заполняют здесь поры и каверны, отмечаются в виде примазок по трещинам и в виде пятен пропитки породы.

Сведения о находках битума в породах юуруского горизонта $\left(S_{1} j r\right)$ нижнего силура относительно скудны. Есть указания на нахождение отдельных гнезд ТПБ на о-ве Хийумаа (п. 45, 46), вблизи Хаапсалу (п. 31) (Озерский, 1844; Гельмерсен, 1857) и в скважине Сааре (п. 16) в Северо-Восточной Эстонии.

Райккюлаский горизонт $\left(S_{1} r k\right)$ в разрезе силурийских образований наиболее богат проявлениями ПБ. По имеющимся данным, в дер. Ваэмла (п. 44) на о-ве Хийумаа в 1905 г. при бурении скважины на воду была получена в небольшом количестве нефтеподобная жидкость (Scupin, 1924). Поиски нефти в этом районе продолжались с перерывами в 1912 1924 гг., но результаты их остались незафиксированными (Einpaul, 1961). В целом разброс известных пунктов битумопроявлений (п. 15, 23, $24,29,39,40$ и др.) в известняках райккюлаского горизонта в территориальном отношении большой (см. рис. 1, табл. I). Характерно наличие пятен пропитки пород ЖПБ, а также ВПБ и ТПБ по кавернам, трещинам, порам, фаунистическим остаткам.

Находки ТПБ в яаниском $\left(S_{1} j n\right)$ и яагарахуском $\left(S_{1} j g\right)$ горизонтах нижнего силура имеются на о-ве Сааремаа (п. 39, 41, 42). Наиболее молодые образования, в которых обнаружены ПБ, - породы паадлаского горизонта $\left(S_{2} p d\right)$ верхнего силура (п. 22,37$)$. Форма проявления - битумная импрегнация по границе чистых известняков с мергелистыми разностями.

Обобщая вышеизложенное, можно заключить, что на территории Әстонии находки ПБ вскрыты в отложениях широкого возрастного диа- 


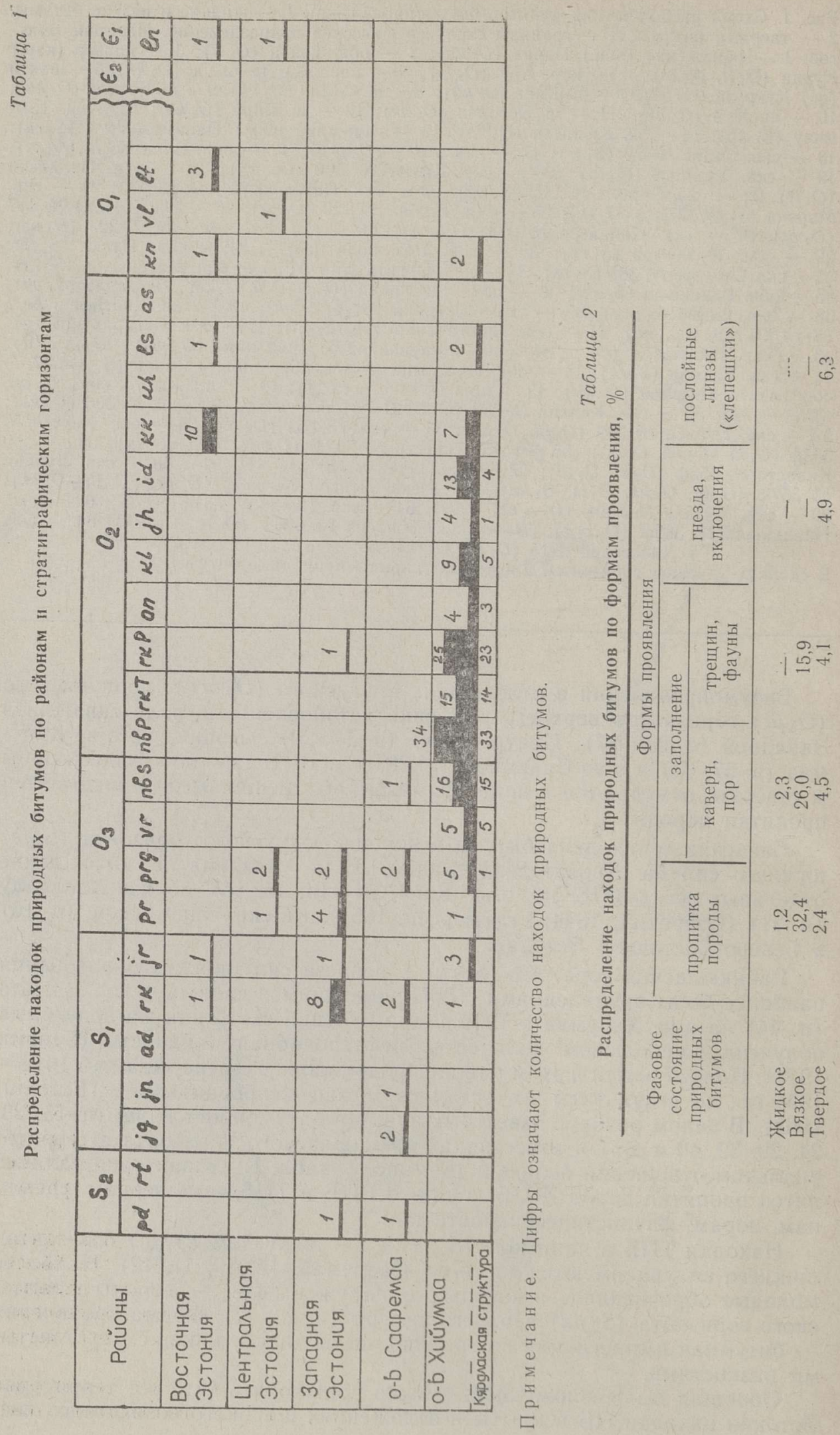




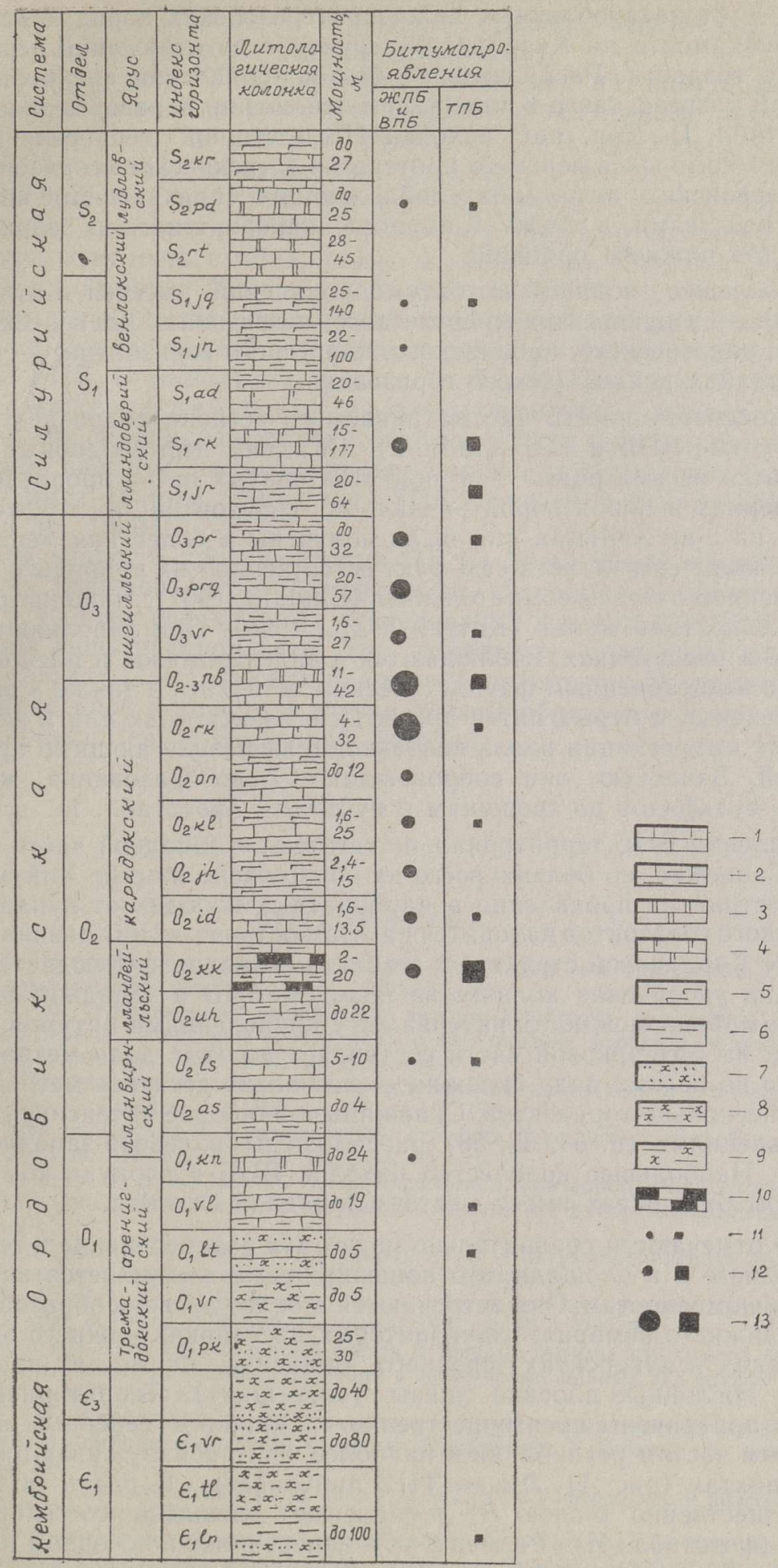

Рис. 2. Битумопроявления в стратиграфическом разрезе нижнего палеозоя Эстонин. 1 - известняк, 2 - глинистый известняк, 3 - доломит, 4 - доломитизированный известняк, 5 - мергель, 6 - глина, 7 - песчаник, 8 - алевролит, 9 - аргиллит, $10-$ кукерсит, 11 - менее 4 проявлений ПБ, $12-4-10$ ПБ, 13 - более 10 ПБ. 
пазона - от раздробленных нижнепротерозойских пород кристаллического фундамента на Кярдлаской структуре до отложений верхнесилурийского возраста. Распределение битумопроявлений как в стратиграфическом разрезе, так и в площадном отношении неравномерное (рис. 1, 2, фототабл. I). Так, нет находок ПБ в мощной терригенной толще вендского комплекса верхнего протерозоя и тискреского горизонта кембрия, в девонских отложениях, обладающих прекрасными коллекторскими свойствами, а также в породах пакерортского и варангуского горизонтов нижнего ордовика.

Наибольшее количество битумопроявлений имеется в отложениях ордовика - в кукерситах кукрузеского, известняках идавереского, кейлаского, раквереского, набалаского, пиргуского горизонтов, и силура в известняках райккюлаского горизонта.

По консистенции ПБ рассматриваемого региона подразделяются на ЖПБ, густые ВПБ и ТПБ (табл. 2). Жидкие нефтеподобные битумы отмечаются весьма редко - в виде желтоватых пятен пропитки, в мелких кавернах и порах пород различных горизонтов и только в дер. Ваэмла на о-ве Хийумаа они были получены в более или менее значительных количествах, хотя сам факт естественной их природы остается в определенной степени сомнительным (Einpaul, 1961). Чаще встречаются густые ВПБ типа мальт (Қаттай и др., 1990). Они заполняют поры и каверны в известняках, наблюдаются в виде примазок и пленок по трещинам и выщелоченным фаунистическим остаткам, а также в виде светло-коричневых и бурых пятен пропитки в известняках или в виде полос битумной импрегнации вдоль контактов с вышезалегающими прослоями мергелей. Зачастую они сопровождают новообразования кальцита, реже - сульфидов по трещинам и пустотам (фототабл. I).

Скопления ВПБ территориально тяготеют к западной части Эстонии, к о-ву Сааремаа, но больше всего их обнаружено на о-ве Хийумаа. Так, все известные их проявления в карбонатных породах от кундаского до вормсиского горизонтов находятся на этом острове, из них львиная доля в районе Кярдлаской структуры (табл. 1). В целом наблюдается четкая тенденция увеличения количества находок ВПБ в западном направлении. Суммарная мощность интервалов с проявлениями битумов по керну скважин на материковой части составляет десятые доли метра, на о-ве Хийумаа по целому ряду скважин - несколько десятков метров и охватывает несколько горизонтов. Скважины с наиболее интенсивными битумопроявлениями (п. $54,55,58)$ расположены в северо-западной части острова. Наибольшее количество находок ВПБ в поркуниском и райккюласком горизонтах имеет место в Западной Әстонии.

ТПБ отмечаются сравнительно редко. Их распределение в геологическом разрезе и в площадном отношении тоже подчиняется определенным закономерностям. Они встречаются в более древних образованиях глинах нижнего кембрия, глауконитовых песчаниках ннжнего ордовика, известняках и кукерситах среднего ордовика. Форма их проявления здесь - послойные плоские линзы («лепешки»). Территориально эти находки приурочены преимущественно к крайним северным и северовосточным частям республики и наиболее часто обнаруживаются в сланцевых шахтах (рис. 1). Линзы ТПБ приурочены к слоям кукерситов (преимущественно к слою $B$ ) и залегают согласно со слоистостью породы (фототабл. II). Размеры их в поперечнике в основном не превышают $30-50 \mathrm{~cm}$, по мощности - 5-10 см. На фоне вмещающего их светло-коричневого кукерсита они резко выделяются черным цветом, границы раздела четкие, иногда на контакте имеется тонкая (несколько мм) каемка сланца более темного цвета (до шоколадного). Никаких изменений в строении залежи и дислокаций на этих участках не замечено. Следует отметить, что на Ленинградском месторожденин кукер- 
ситов одна из линз ТПБ была вскрыта в прослое известняка «плита» промпачки сланца (фото) (Клубов, Уров, 1988).

По внешнему виду ТПБ («лепешки») похожи на каменный уголь. Это хрупкая и легко измельчаемая порода с блестящим раковистым изломом, твердость по шкале Мооса - $2-3$, плотность - $1,10-$ $1,26 r / \mathrm{cm}^{3}$. По составу и свойствам их относят к классу асфальтитов (Аарна, 1959; Люткевич, Курбатская, 1964; Каттай, Кундель, 1987 и др.) .

Локальные скопления ТПБ в отложениях верхнего ордовика и нижнего силура отмечены в обнажениях и скважинах только в Западной Эстонии и на островах Хийумаа и Сааремаа. Они представлены в виде мелких гнезд и жильных образований, вкраплений, тонкой присыпки по кальциту на стенках каверн и трещин, корочек по фауне, зачастую ассоциируют с ВПБ. В нескольких пунктах (п. 54,61) западнее Кярдлаской структуры маломощные $(10-15$ см) линзы песчаника в идавереском горизонте имеют сплошную пропитку битумом. Последний как бы цементирует породу, заполняя ее межзерновое поровое пространство (табл. I). По имеющимся данным, этот тип ТПБ отнесен к классу асфальтов (Каттай и др., 1990).

В целом вопрос о происхождении ПБ на территории республики в отложениях широкого стратиграфического диапазона остается дискуссионным и требует специальных исследований и отдельного рассмотрения. Можно лишь предполагать, что локальные скопления мальты и асфальта, развитые в западных районах и на Западно-Әстонском архипелаге, имеют иной источник и другие условия образования, чем «лепешки» асфальтита Северо-Восточной Әстонии.

\section{Л И Т Е РА Т У Р А}

Аарна А. М. Об образовании горючих сланцев Эстонского месторождения // Генезис твердых горючих ископаемых. М., 1959, 57-68.

Гельмерсен Г. П. О правильных трещинах в нижнесилурийском известняке Эстляндского берега, разрушение его волнами и нахождение асфальта в этой форма ции // Горный ж., 1857, ч. II, кн. 4, 84-94.

Гревингк $K$. Нахождение коренного месторождения каменного угля в Остзейских іро винциях // Горный ж., 1868, ч. III, кн. 7, 172-174.

Кала Э., Пуура В., Сууроя К. Главные черты строения Кярдлаского погребенного кратера // Изв. АН ЭССР. Геол., 1984, 33, № 1, $1-7$.

Кала Э. А., Пуура В. А., Сууроя К. А. О Кярдлаской кратерообраэной структуре на о. Хийумаа // Локальные структуры Белоруссии и Прибалтики. Вильнюс, 1978, $88-91$.

Каттай В. А., Клубов Б. А., Кала Э. А., Сууроя К. А. О битумопроявлениях на острове Хийумаа // Горючие сланцы, 1990, 7, № 1, 10-18.

Каттай В. А., Кундель Х. А. Включения твердых битумов в кукерситах, состав и свойства этих битумов // Горючие сланцы, 1987, 4, № 1, 22-29.

Клубов Б. А., Уров К. Э. Вещественный состав и твердые битумы кукерского горизонта Прибалтийского сланцевого бассейна в свете новых данных // Горючие сланцы, 1988 , 5, № 1, 34-45.

Люткевич E. М., Курбатская А. П. О генезисе асфальтитовых «лепешек» и «галек» нижнего кембрия и среднего ордовика Прибалтики // Геохим. сб., вып. 9. М., 1964, 101-111.

Люткевич E. М. Нефтеносность Прибалтики // Геология и нефтеносность палеозоя Южной Прибалтики. Вильнюс, 1965, 107-127.

Люткевич $E . M$. История поисков нефти в Прибалтике и ее уроки // Нефтепоисковые критерии Прибалтики и методы их изучения. Вильнюс, 1970, 7-16.

Озерский $A$. Д. Геогностический очерк Северо-Западной Эстляндии // Горный ж., 1844, ч. II, кн. $5,157-208$.

Орлов Н. А., Успенский В.А. Минералогия каустобиолитов. М., 1936.

Паасикиви Л. Б., Закашанский М. С. Перспективы нефтеносности Прибалтики // Обзор ВИЭМС, вып. 34, М., 1965.

Doss, B. Uber die Möglichkeit von der Erbohrung von Naphtalagerstätten bei Schmarden in Kurland // Korresp. Bl. Naturf. Ver. Riga, 1900, XLIII, 157-212. 
Doss, B. Ein Vorkommen von Grahamit im Silurkalk bei Kunda in Estland // Zbl. Miner., $1914,605-615$.

Eichwald, E. Dritter Nachtrag zur Infusorienkunde Russlands // Bull. Soc. Nat. Moscou, 1852, XXV, N 11, 388-536.

Einpaul, A. Naftaotsimisest Hiiumaal XX sajandi esimesel veerandil // Eesti Loodus, 1961, nr. $4,235-236$.

Kogerman, $P$. The occurrence, nature and origin of asphaltites in limestone and oil shale deposits in Estonia // J. Inst. Petrol. Technol., 1933, 19, N 113, 215-222.

Kupfier, A. Bericht über eine geologische Reise in den südlich und nördlich von Hapsal gelegenen Landstrecken und auf den Inseln Moon, Oesel und Dago // Sb. Naturf. Ges. Dorpat, 1869, 2, 249-256.

Müürisepp, K. Uhest uuest asfaltiidileiust Eestis // Eesti Loodus, 1962, nr. 5, 286-289.

Pahlen, A. Uber ein Mineral von kohleähnlichem Habitus // Rev. Zeit, 1911, 29. Nov.

Palmre, H. Maaõli tunnustest Paluküla kivimurrus Hijumaal // ENSV TA Toim. Keemia. Geol., 1967, 16, nr. 4, 344-345.

Scupin, H. Zur Petroleumfrage in den baltischen Ländern // Acta Univ. Tartu, 1924, A6, H. 11,13 .
Институт геологии
Академии наук Эстонской ССР
Поступила в редакцню
30/V 1989

\section{Vello KATTAI, Elmar KALA, Kalle SUUROJA}

\section{LOODUSLIKE BITUUMENITE LEVIK EESTI TERRITOORIUMIL}

On iseloomustatud looduslike bituumenite pindalalist ja stratigraafilist levikut Eesti aluspõhjas. Neid on leitud aluskorra kivimeist (Kärdla struktuurii), alamkambriumi Lontova kihistu savidest ning peaaegu kogu ordoviitsiumi ja siluri karbonaatkivimite kompleksist. Kõige sagedamini esineb neid kesk- ja ülemordoviitsiumi (Kukruse, Idavere, Keila, Rakvere, Nabala ja Pirgu lade) ning alamsiluri Raikküla lademe karbonaatsetes kivimites. Esinevad järgmised looduslike bituumenite klassid: vedelad naftataolised bituumenid, viskoossed maltad, tahked asfaldid ja asfaltiidid. Nafta, malta ja asfaldi ilminguid on peamiselt leitud Lääne-Eesti saartelt ja Mandri-Eesti lääneosast, asfaltiidi ilminguid aga Kirde-Eestist. Malta esineb kivimites kas immutuslaikudena või täidab poore, kaverne ja lōhesid, asfalti on pisikeste pesadena ja lōhetäidetena, asfaltiiti lamedate läätsedena. Bituumenite tekkeküsimused nốuavad eriuuringuid.

\section{Vello KATTAI, Elmar KALA and Kalle SUUROJA}

\section{THE DISTRIBUTION OF NATURAL BITUMENS ON THE TERRITORY OF ESTONIA}

The paper deals with the occurrence and stratigraphical distribution of natural bitumens in Estonian bedrock, found in the rocks of the crystalline basement (Kärdla structure), clays of the Lower Cambrian Lontova Formation and in almost the whole complex of Ordovician and Silurian carbonate rocks. They have been recorded the most frequently in carbonate rocks of the Middle and Upper Ordovician Kukruse, Idavere, Keila, Rakvere, Nabala and Pirgu Regional Stages and in the Lower Silurian Raikküla Regional Stage. The following types of natural bitumen are distinguished: liquid petroleumlike substances, viscid malthas, solid bitumen and asphaltites. Occurrences of petroleum, maltha and solid bitumen have been established mostly on the islands and the western part of the Estonian continent, asphaltites, however, have been found in $\mathrm{NE}$ Estonia. Maltha occurs in rocks as spots or fills pores, caverns and cracks, solid bitumen is found in the form of small pockets and vein fillings, asphaltites as flat lenses. The formation of bitumens is still open to debate and needs special investigation. 